Saving the Children 
Edited by James Vernon

I. The Peculiarities of Liberal Modernity in Imperial Britain, edited by Simon Gunn and James Vernon

2. Dilemmas of Decline: British Intellectuals and World Politics, 1945-1975, by Ian Hall

3. The Savage Visit: New World People and Popular Imperial Culture in Britain, I7IO-I795, by Kate Fullagar

4. The Afterlife of Empire, by Jordanna Bailkin

5. Smyrna's Ashes: Humanitarianism, Genocide, and the Birth of the Middle East, by Michelle Tusan

6. Pathological Bodies: Medicine and Political Culture, by Corinna Wagner

7. A Problem of Great Importance: Population, Race, and Power in the British Empire, I9I8-1973, by Karl Ittmann

8. Liberalism in Empire: An Alternative History, by Andrew Sartori

9. Distant Strangers: How Britain Became Modern, by James Vernon

Io. Edmund Burke and the Conservative Logic of Empire, by Daniel I. O’Neill

II. Governing Systems: Modernity and the Making of Public Health in England, I830-1910, by Tom Crook

12. Barbed-Wire Imperialism: Britain's Empire of Camps, 1976-1903, by Aidan Forth

13. Aging in Twentieth-Century Britain, by Charlotte Greenhalgh

I4. Thinking Black: Britain, 1964-1985, by Rob Waters

15. Black Handsworth: Race in Ig80s Britain, by Kieran Connell

16. Last Weapons: Hunger Strikes and Fasts in the British Empire, $1890-1948$, by Kevin Grant

17. Serving a Wired World: London's Telecommunications Workers and the Making of an Information Capital, by Katie Hindmarch-Watson

18. Imperial Encore: The Cultural Project of the Late British Empire, by Caroline Ritter

19. Saving the Children: Humanitarianism, Internationalism, and Empire, by Emily Baughan 


\section{Saving the Children}

HUMANITARIANISM, INTERNATIONALISM, AND EMPIRE

Emily Baughan

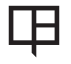

U NIVERSITY OF CALIFOR NIA PRESS 
The publisher and the University of California Press

Foundation gratefully acknowledge the generous support of the Abmanson Foundation Endowment Fund in Humanities.

University of California Press

Oakland, California

(C) 2022 by Emily Baughan

Library of Congress Cataloging-in-Publication Data

Names: Baughan, Emily, I988- author.

Title: Saving the children : humanitarianism, internationalism, and empire / Emily Baughan.

Other titles: Berkeley series in British studies; I9.

Description: Oakland, California : University of California Press, [2022] | Series: Berkeley series in British studies ; I9 | Includes bibliographical references and index.

Identifiers: LCCN 2021014315 (print) | LCCN 2021014316 (ebook) | ISBN 9780520343719 (cloth)| ISBN 9780520343726 (paperback) | ISBN 9780520975118 (epub)

Subjects: LCSH: Save the Children Fund (Great Britain)_History. | Humanitarianism-Political aspects—2oth century.

Classification: LCC BJi 475.3 . B37 2022 (print) | LCC BJi 475.3 (ebook) | $\operatorname{DDC}_{361.2 / 6-\mathrm{dc} 23}$

LC record available at https://lccn.loc.gov/2021014315

LC ebook record available at https://lccn.loc.gov/2021014316

Manufactured in the United States of America

$\begin{array}{llllllllll}31 & 30 & 29 & 28 & 27 & 26 & 25 & 24 & 23 & 22\end{array}$

$\begin{array}{llllllllll}\text { IO } & 9 & 8 & 7 & 6 & 5 & 4 & 3 & 2 & \text { I }\end{array}$ 
For my mum

Annie Baughan (née Rutherford) 1958-2019 
